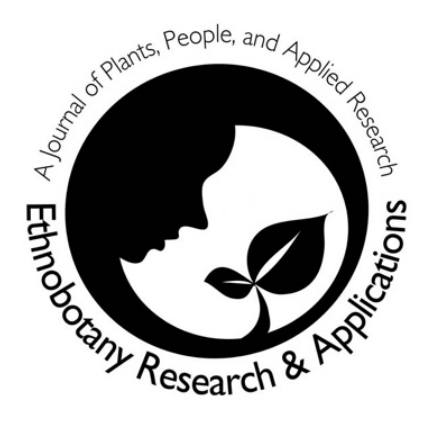

\section{Tree Planting Stakeholder analysis in the Ugandan Albertine Rift}

\author{
Charles L. Tumuhe, Juliet Kiguli
}

\section{Research}

\begin{abstract}
Background: Trees provide ecosystem services, for example, by preserving soil fertility and sequestering carbon. They contribute 8.7 percent to Uganda's national economy. Due to the ecosystem services trees provide, several stakeholders in Uganda have intervened to increase tree cover in the landscape. These stakeholders include; Ministry of water and Environment, National Forestry Authority, World vision Uganda (WVU) and licensed individual tree planters in forest reserves. The success of their interventions depends on several factors. Among these factors, probably, the least studied is the influence of different stakeholders in promoting tree planting. This paper assesses the different stakeholders in tree planting in Kiryanga Sub County, Albertine rift region, Uganda.
\end{abstract}

Methods: The analysis was conducted in a stakeholder workshop to identify stakeholders' potential roles, relationships, power and influence on tree planting. The stakeholder; register, analysisgrid, and matrix were respectively used to identify and categorize stakeholders.

Results: The identified stakeholders were; community leaders, Civil Society Organizations (CSOs), government institutions, individual farmers and farmer groups. Farmers, Local Government (LG) CSOs; WVU and Uganda Rural Development and Training (URDT) were important stakeholders in tree planting. The LG will provide seedlings, train, and guide and mobilize farmers during tree planting. WVU will promote regenerating trees from stumps, roots, and naturally growing tree seedlings. URDT will sensitize and train farmers in tree planting. Farmers also have to be engaged with to provide land and labour for tree planting.
Conclusion: Tree planting interventions ought to be implemented after thorough understanding and engagement of these key stakeholders.

Keywords: stakeholder analysis, Albertine Rift, tree planting, forest cover

\section{Mubugufu}

Emiti eyamba obuhangwa kulinda eitaka hamu nokwihamu orwoya orubi. Emiti ereta sente ezikuhikya obucweeka 8.7 hakikumi omu Uganda. Aha bw'emigaso y'emiti, baingi omu Uganda barugireyo okwongezaaho hali emiti eyebyairwe omu mwanya ogulikwonka. Ebitongole nka ekihanda ekwa amaizi na ebitwehingilirize, ekitongole kyebibira, Warudi Vizoni hamu abantu kinoomu abahairwe ebaruha kubyaara emiti omubibira. Obusinguzi bwabu niburuga hali bingi. Abakukwatwaaho abembaganiza omukubyara emiti tibasomerwe kumanywa ekikumara. Okuseruliriza kunu kuli hali abakukwatwaho omukubyaara emiti omwi bohorra lya Kiryanga omu ekicweeka kya enyanja mwitanzige, Uganda.

\section{Correspondence}

Charles L. Tumuhe ${ }^{1,2 *}$ Juliet Kiguli ${ }^{1}$

${ }^{1}$ Department of environmental management, Makerere University, P. O. BOX 7062, Kampala, Uganda

${ }^{2}$ African Rural University, P. O. BOX 24, Kagadi, Uganda

*Corresponding author: tumchaz34@gmail.com

Ethnobotany Research \& Applications 18:7 (2019) 
Okucencura kukakorwa omumusomo kumanyirra emirimo eya abakukwatwaho, obukwate bwabu, amaani nobusobozi baine omukubyara emiti. Orukarra, akabokisi hamu n'ekimeeza bikakozesebwa kumanyirra, no'kusengeneka abakukwatwaho. Abakukwatwaho abakuru nibo, abebembezi, ekitongole nka Araditi, warudi vizoni, gavument, abalimi, hamu na ebitebe bya abalimi. Gavumenti y'okuleeta endokwa, kutendeka kuhabura, n'okujugumbya abalimi kubyara emiti. Warudi vizoni y'okumeza emiti habikonge. Araditi y'okujugumbya kandi netendeka abalimi. Abalimi nibo bakuhayo eitaka kandi nibabyara emiti. Okubyara emiti kwoona nikutekwa kusoka nokwetegereza hamu n'okukwataniza n'abakukwatwaho abakuru boona.

Ebigambo ebikuru: Kucencura abakukwatwaho, Ekicweeka ekya enyanja Mwitanzige, kubyaara emiti, omwanya oguroho ebibira

\section{Background}

Trees, forests and woodlands cover about 14 percent of Uganda's land surface, but the government is anticipating to expand it to 24 percent by 2040 (National Planning Authority 2013). Uganda also pledged to restore 2.5 million hectares of deforested land by 2020 in the Bonn Challenge (Ministry of Water and Environment 2016a). This is because trees provide ecosystem services like regulating climate, preserving soil fertility and sequestering carbon (Salmond et al. 2014). Furthermore, they contribute 8.7 percent to Uganda's Gross Domestic Product (Ministry of Water and Environment 2016b) and thus conserving them is vital to peoples' livelihoods. Therefore, there have been several efforts by different stakeholders to plant trees in Uganda notably, National Forestry Authority (NFA), Ministry of water and environment (MWE), World Vision Uganda (WVU) and licensed private tree planters in forest reserves. Uganda has also taken up the Reducing Emissions from Deforestation and forest Degradation + the role of conservation, sustainable management of forests and enhancement of forest carbon stocks (REDD+) to enhance forest cover restoration (Ministry of Water and Environment 2016b) through tree planting. However, these stakeholders' efforts have not attained anticipated success because tree cover is still reducing. Uganda lost more than half of its forests in 25 years due to, among other factors, uncoordinated stakeholders and inadequate funds for conservation efforts (IUCN 2018). The forest cover may not be restored to the anticipated 24 percent by 2040 unless key stakeholders are absorbed in all tree planting processes.
The efforts to restore the lost forest cover should involve involvement of several stakeholders including government, development partners and Civil Society Organizations (CSOs) both local and international such as International Union for Conservation of Nature and Natural Resources (IUCN) (IUCN 2018). A stakeholder in tree planting is an individual, interest group, or organization, who may affect, be affected by, or perceive itself to be affected by a decision, activity, or outcome related to tree planting (Weperen 2013). Stakeholders in forest conservation could be farmers who own the planted forests, farm workers who provide labour for tree planting, middle men for tree products, extension workers, environmentalists, politicians, the forestry authority (NFA), government, CSOs, academics and researchers, donors, consultants and community based organizations. Stakeholders influence tree planting decisions for example when and which tree species to plant. The stakeholders have different power, influence and importance. According to Mayers (2005), importance of a stakeholder is understood in terms of their role in achieving anticipated results. Influence is judged in terms of the power they can exert over tree planting process and outcome. Stakeholder power can be understood as the extent to which stakeholders are able to persuade or coerce others into making decisions and following certain courses of action. Power may derive from the stakeholders' position or possession (Mayers 2005). For any tree planting program, stakeholder identification and their eventual participation should be considered at the beginning of tree planting interventions. Engagement with stakeholders early in decision-making is indispensable if forest cover is to be restored through a sustainable and participatory tree-planting process (Lin \& Lin 2015). Stakeholder analysis identifies people and institutions that may support or oppose the planned interventions and how each can be dealt with (Mayers 2005). Stakeholder analysis should therefore always be prioritized to avoid inflaming conflicts when implementing tree planting interventions (Weperen 2013). This study focused on tree planting stakeholders in Kiryanga Sub County (SC), located in the Albertine rift region, Uganda.

\section{Materials and Methods \\ Description of study area}

Kiryanga SC $\left(1^{\circ} 5^{\prime} 40^{\prime \prime} \mathrm{N}, 31^{\circ} 3^{\prime} 32^{\prime \prime} \mathrm{E}\right)$ is located in the Ugandan Albertine rift region (Figure 1). The Uganda portion of the Albertine rift extends from Budongo Forest/Murchison Falls National Park in the north down to Mgahinga National park in the south. There are 79 central forest reserves and 21 local forest reserves managed by the districts (Plumptre 
2002). Modified Equatorial vegetation type mainly covers Kiryanga SC (Langdale et al. 1964). This type of vegetation used to be equatorial in nature but has been modified as a result of human activity (Kakuru et al. 2014). The rainfall in Kiryanga SC ranges from
$1000 \mathrm{~mm}$ to $1500 \mathrm{~mm}$ and temperature, $15^{\circ} \mathrm{C}$ to $30^{\circ} \mathrm{C}$. It has 24,622 people and 5,483 households $(\mathrm{HH})$ (Uganda Bureau of Statistics 2016).

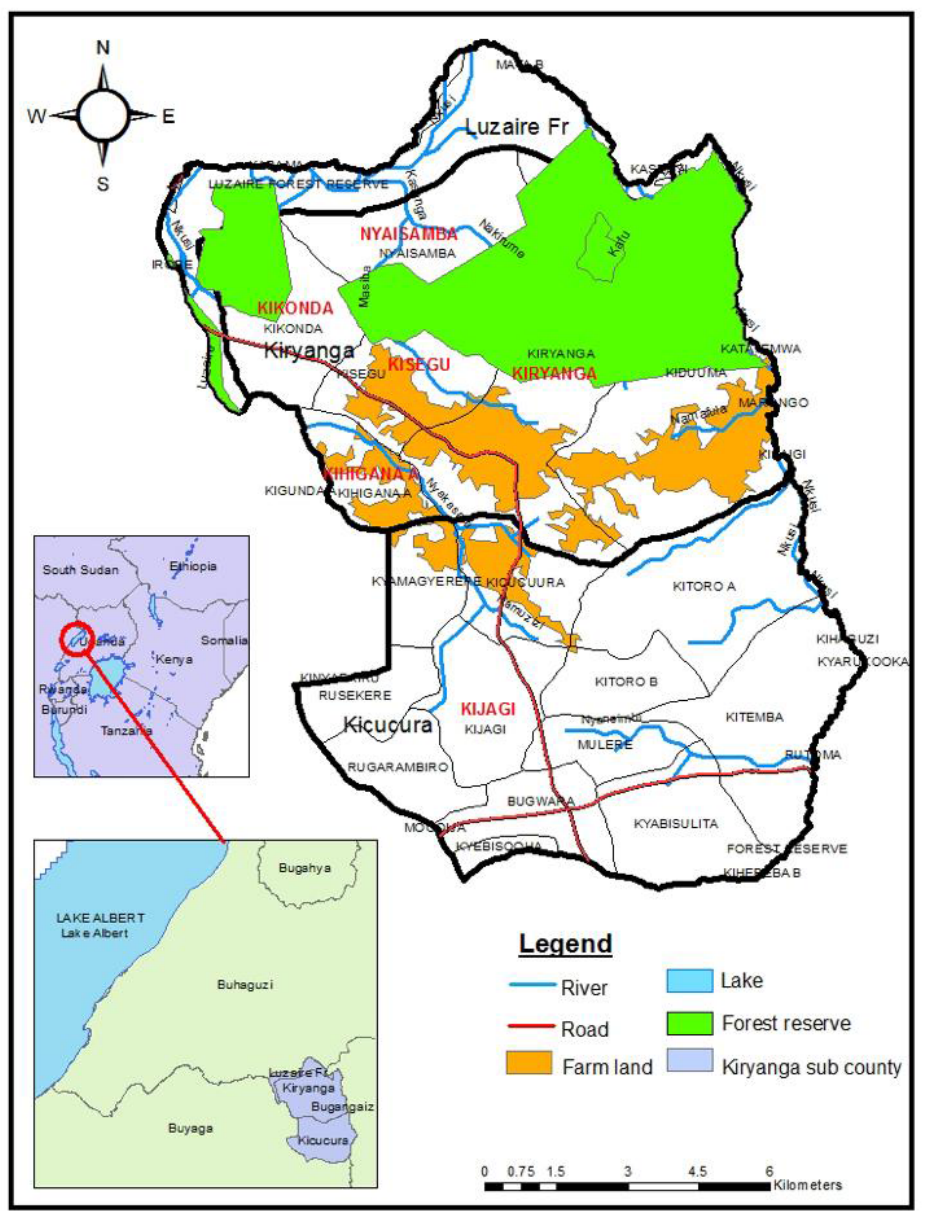

Figure 1. Location of the study area. The maps show location of the Albertine rift region and Kiryanga SC (study area)

Firstly, Kiryanga SC was selected because its rate of forest cover loss is 10 percent per year and about 5 times higher than the Uganda (1.8 percent) national forest cover loss rate (Ministry of Water and Environment 2016b). Secondly, it is located in the Albertine Rift which is home to over 1100 endemic plant and animal species and has more registered species of vertebrates than any other part of Africa. The Albertine Rift region is very important for biodiversity conservation in western Uganda. It is an endemic bird area and biodiversity hotspot. It also contains some of the richest areas in Africa for mammal and bird species. Conservation International listed the Albertine Rift as one of the world's most endangered areas, based on levels of species endemism and rates of habitat destruction (National Environmental Management Authority 2009). Kiryanga SC is one of the eight sub counties, the Murchison-Semliki REDD+ Project has been involved in incentive-based tree planting mainly using free tree seedlings and cash incentives (Wieland 2012). The other stakeholders include; National Environmental Management Authority (NEMA), World Wide Fund for nature (WWF), Uganda Rural Development and Training program (URDT), WVU and Chimpanzee Sanctuary and Wildlife Conservation Trust (Gross-Camp et al. 2012). Thirdly, four of the sixteen forest reserves in the Kagadi sector border with Kiryanga SC and these 
house chimpanzees living outside protected areas (Nyakana \& Nyakana n.d.).

The qualitative stakeholder ( $\mathrm{SH}$ ) analysis studydesign was undertaken (Hyder et al. 2010, Namazzi et al. 2013, Richards \& Panfil 2011). SH analysis was carried out in March 2018 in Kiryanga SC, Western Uganda in a three-step multi-stakeholder process. First, researcher and key informants $(n=11)$ developed a stakeholder register. The key informants were District and SC production staff (technical and political). Second, categorizing stakeholders using the stakeholder analysis grid (Figure 2). Stakeholders were put in five categories by same participants (used in step one) as described below; a) driver-stakeholders have high power, influence and high agreement to tree planting practice and promotes it; b) blocker-stakeholders have high levels of power and influence in tree planting, but highly oppose the practice; c) supporter-stakeholders promote the practices but whose influence and power is limited (on their own); d) bystander-stakeholders disagree to the practices but with low influence and support; e) abstainerstakeholders are neutral to the practices, but may or may not have influence (Namazzi et al. 2013).

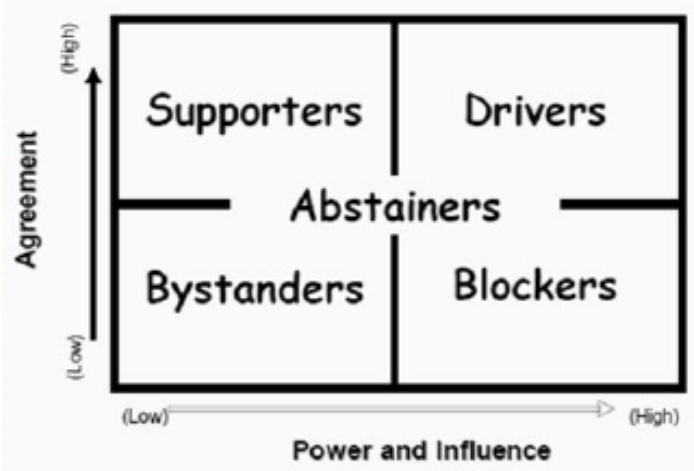

Figure 2. Stakeholder analysis grid for categorizing stakeholders. The category of a stakeholders depends on their level of power and influence and agreement in tree planting.

The percentage of each stakeholder category was computed. Third, stakeholder characteristics were analyzed in a stakeholder workshop (for only drivers and supporters). The characteristics related to their potential roles, interests, and positions in tree planting. The participants also agreed on the suitable strategy to deal with each stakeholder. The strategies to deal with $\mathrm{SH}$ were in terms of empowering them, engaging them continuously, involving them further and consulting them further. To get the relationship, importance and influence of the stakeholders, circular and triangular pieces of different sizes were used (i.e. small circle/triangle = very important/influential, middle sized circle/triangle $=$ significant importance/influence and large circle/triangle $=$ very important/influential. The cut pieces were displayed on a news print and the proximity or overlapping (touching) of circles represented the relationship among stakeholders. Images of responses were captured and later transcribed, written in Microsoft word and thematically analyzed (Richards \& Panfil 2011).

\section{Results}

Stakeholders in tree planting in Kiryanga Sub County - Supporters, drivers and bystanders

According to Table 1, the identified stakeholders in tree planting were leaders (i.e. religious, cultural and political), CSOs (WVU and URDT), government (SC, District Local Government (LG), and NFA) farmers and Collaborative Forest Management (CFM) farmer groups and NFA. Apart from the district LG, the stakeholders were from within the study area. Majority of the stakeholders were supporters (36 percent), drivers (36 percent) and bystanders (28 percent). There were no abstainers and blockers. These stakeholders complement each other but have different power, influence, and importance. Stakeholders' power is shown in Table 2.

\section{Importance and influence of stakeholders}

Figure 3 shows that government (District and SC) were the most important stakeholders (with biggest circles). The government also had the biggest power and influence (biggest triangles). Farmers and CSOs had moderate importance. The CSOs had moderate power and influence but farmers' power and influence were the least. NFA was the least important stakeholder and with least power and influence in tree planting. A highly important stakeholder with high power did not necessarily have high influence in tree planting but each one had a unique interest in tree planting.

\section{Interests of stakeholders in tree planting}

All stakeholders had interest in tree planting in several ways. The SC and District LG are concerned about improvement in societal wellbeing through revenue generation from tree planting. WVU and URDT envision tree planting as one of the means of improving children's and women's welfare respectively. NFA wants farmers to plant trees because they can produce farm-based wood products thereby sparing central-forest trees. Farmers and their groups are concerned about improved peoples' wellbeing from incomes and good climate obtained from tree planting. Stakeholders' interests and roles were interlinked but less conflicting and these determined the relationship 
among the stakeholders regarding tree planting

(Table 3)

Table 1. Driver, supporter and bystander stakeholders in tree planting in Kiryanga SC. The classification is based on stakeholders' level of agreement and influence in tree planting.

\begin{tabular}{llll}
\hline Stakeholder in tree planting & $\begin{array}{l}\text { Influence in } \\
\text { tree planting }\end{array}$ & $\begin{array}{l}\text { Level of } \\
\text { agreement }\end{array}$ & $\begin{array}{l}\text { Classification of } \\
\text { SH }\end{array}$ \\
\hline Cultural leaders & Moderate & Moderate & By-standers \\
$\begin{array}{l}\text { Individual farmers } \\
\text { Local council (LC) leaders }\end{array}$ & Low & $\begin{array}{l}\text { High } \\
\text { High }\end{array}$ & $\begin{array}{l}\text { Supporters } \\
\text { Supporters }\end{array}$ \\
$\begin{array}{l}\text { CFM farmer groups } \\
\begin{array}{l}\text { Non-governmental } \\
\text { organizations (URDT World } \\
\text { vision Uganda) }\end{array}\end{array}$ & Low & High & Supporters \\
$\begin{array}{l}\text { Government institutions } \\
\text { (District LG, Sub County LG, } \\
\text { NFA) }\end{array}$ & High & High & Drivers \\
Nursery bed operators & High & High & Drivers \\
\hline
\end{tabular}

Table 2. Stakeholders' power, influence and importance in tree planting

\begin{tabular}{|c|c|c|}
\hline Stakeholder & Importance & $\begin{array}{l}\text { Power and } \\
\text { Influence }\end{array}$ \\
\hline Kiryanga Sub County LG & High & High \\
\hline Kagadi District LG & High & High \\
\hline Farmers & Moderate & Low \\
\hline CSOs (WVU, URDT) & Moderate & Moderate \\
\hline NFA & Low & Low \\
\hline
\end{tabular}

Table 3. Supporter and driver stakeholders in tree planting in Kiryanga SC

\begin{tabular}{|c|c|c|c|}
\hline $\begin{array}{l}\text { Stakeholder in tree } \\
\text { planting }\end{array}$ & Potential roles of $\mathrm{SH}$ in tree planting & SH interests & $\begin{array}{l}\text { Classification } \\
\text { of SH }\end{array}$ \\
\hline Community leaders & $\begin{array}{l}\text { Lobby, sensitize farmers, monitor tree } \\
\text { planting projects }\end{array}$ & Improved $\mathrm{HH}$ income & Supporter \\
\hline Farmers \& their groups & sensitize, plant trees & revenue, tree products & Supporter \\
\hline URDT (CSO) & $\begin{array}{l}\text { Sensitize farmers, supply tree } \\
\text { seedlings }\end{array}$ & $\begin{array}{l}\text { the seedling market, FR } \\
\text { conservation }\end{array}$ & Supporter \\
\hline WVU (CSO) & $\begin{array}{l}\text { Sensitize farmers to plant, supply } \\
\text { seedlings, monitoring }\end{array}$ & $\begin{array}{l}\text { good environment for the } \\
\text { children }\end{array}$ & Driver \\
\hline Kiryanga SC (lower LG) & $\begin{array}{l}\text { Lobby, sensitize \& mobilize farmers, } \\
\text { training farmers, monitoring \& } \\
\text { seedlings supply }\end{array}$ & $\begin{array}{l}\text { increased tax base through } \\
\text { increased } \mathrm{HH} \text { income }\end{array}$ & Driver \\
\hline $\begin{array}{l}\text { Kagadi District (Local } \\
\text { government) }\end{array}$ & $\begin{array}{l}\text { Seedling supply, lobbying, sensitize, } \\
\text { monitor, guide tree planting and } \\
\text { felling, training farmers }\end{array}$ & $\begin{array}{l}\text { increased tax base, FR } \\
\text { conservation }\end{array}$ & Driver \\
\hline $\begin{array}{l}\text { NFA (government } \\
\text { institution) }\end{array}$ & $\begin{array}{l}\text { Seedling supply, protection of trees, } \\
\text { training, sensitize, monitor }\end{array}$ & FR conservation & Driver \\
\hline
\end{tabular}




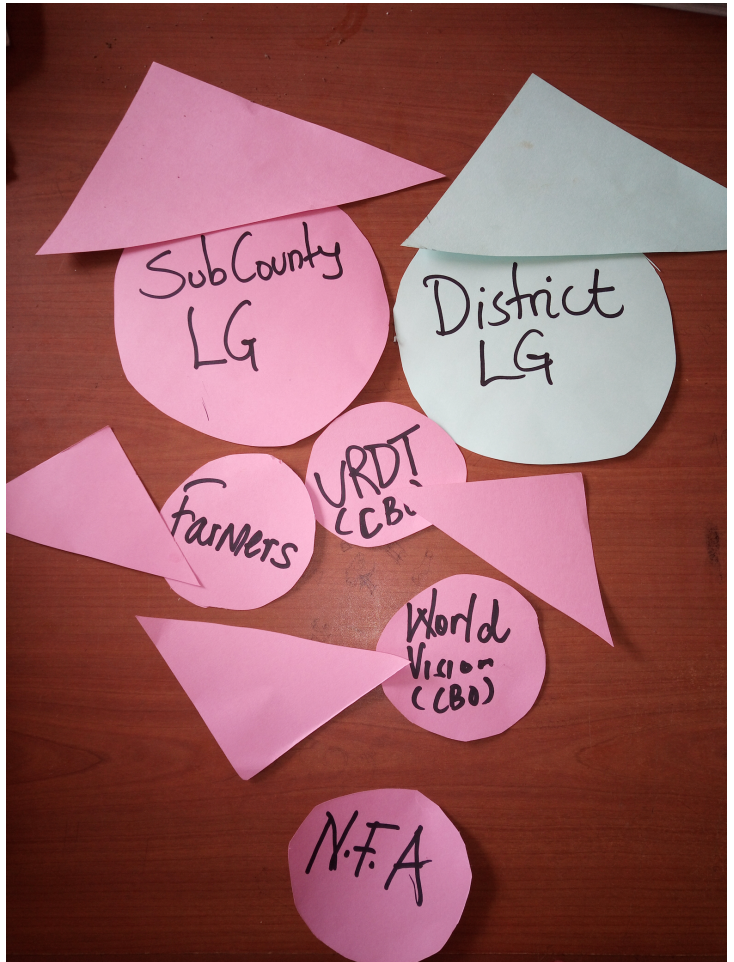

Figure 3. Power, importance, influence of stakeholders: Blue color = outsider stakeholder; Pink color = insider stakeholder; Circle = importance of stakeholder; Triangle $=$ power and influence. The figure also shows relationship among the stakeholders in tree planting. Stakeholders whose circles are touching or closer are more related in terms of their roles in tree planting

\section{Relationship among stakeholders}

The degree of relationship among stakeholders was shown by circular objects in Figure 3. The circles for the government (District, SC), farmers and URDT (a CSO) were touching implying that they all have a significant relationship among each other. Unlike NFA (a government authority), WVU (a CSO) was closely related to all stakeholders (Figure 3). All stakeholders except NFA had high capacity and motivation to promote tree planting. These stakeholder relationships were only in regard to tree planting and thus the "related stakeholders" may not be related in other aspects.

\section{Strategy to deal with each Stakeholder}

The strategy suggested to deal with each stakeholder was according to their importance and influence. The community leaders and government (SC, District, and NFA) ought to be continuously engaged in planning activities like budgeting and activity scheduling for tree planting interventions for their technical guidance. The CSOs (URDT and WVU) ought to be involved further in these planning activities to receive their support. The farmers and their groups (e.g. CFM groups) ideally need to be involved in all tree planting processes but need to be first empowered through training on the importance and recommended practices of tree planting. They may also be empowered with farm inputs mainly tree seedlings (Table 4).

Table 4. Strategy to deal to deal with each stakeholder

\begin{tabular}{ll}
\hline $\begin{array}{l}\text { Strategies to deal with } \\
\text { each SH }\end{array}$ & $\begin{array}{l}\text { Stakeholder in tree } \\
\text { planting }\end{array}$ \\
\hline Empower and involve & Farmers \& their CFM \\
in all processes & groups \\
Involve further in & URDT (CSO), WVU \\
planning & (CSO) \\
Continuously engage in & Kiryanga SC \\
planning & (government) Kagadi, \\
& District (government), \\
& NFA (government), \\
& Community leaders \\
& Kiryanga SC \\
(government) Kagadi, & District (government), \\
Consult further & Com (government), \\
& Community leaders \\
\hline
\end{tabular}

\section{Discussion}

The most important stakeholders were; leaders, farmers and their groups, CSOs (URDT and WVU), and government institutions. The government was the most important, powerful and influential stakeholder. This is because it is mandated to train, guide and mobilize farmers during tree planting. Government also supplies tree seedlings and eventually monitors their beneficiaries. CSOs (WVU, URDT) were moderately important. WVU promotes the Farmer Managed Natural Regeneration (FMNR) approach in Kiryanga SC. FMNR is the regeneration of trees from stumps, roots, and naturally growing seedlings. The aim of WVU is to create a favorable environment for the welfare of children (World Vision Uganda 2014). URDT houses Kagadi Kibaale Community Radio (KKCR) which runs weekly environmental radio talk shows to sensitize and train farmers in the study area on tree planting (Kakuru et al. 2014). Farmers and their CFM groups are important because they are to plant trees, provide land and also sensitize others to plant. The CFM groups work with conservation agencies and government institutions to promote tree planting and forest conservation (National Environmental Management Authority 2016). The identified tree planting stakeholders depend on existing institutional and political structure in the community and procedure followed during stakeholder analysis 
as reported in previous studies (Peskett et al. 2011). Stakeholders differ in potential roles, power, and influence. Some stakeholders are more influential but with limited power to influence key tree planting decisions. Others have high power (e.g. political leaders) but may not easily influence tree planting. This is why tree-planting project-managers make choices of which stakeholders and when to engage them to reduce conflicts among them (Weperen 2013). A proper stakeholder engagement framework determines who should participate, when and how (Luyet et al. 2012). The most influential and powerful stakeholders are ideally engaged earlier and throughout the entire tree planting process. Stakeholders have diverse interests and goals. A governance framework structure ensures stakeholders joint participation and harmonizes their interests for a win-win situation. It is common to assemble all legitimate stakeholders together due to their complementary potential roles (Lin \& Lin 2015) but a balance of their interests is inevitable (Mayers 2005).

\section{Conclusion}

Tree planting requires the engagement of various stakeholder categories. The important stakeholders to be engaged within tree planting interventions in the study area include; Kiryanga SC and Kagadi District Local Governments and WVU and URDT CSOs. These have complementary roles though varying interests, power and influence. Generally, all government institutions and CSOs in environmental conservation need to be consulted and engaged right from the beginning of tree planting processes to ensure tree planting interventions succeed in Uganda. Farmers should be empowered through training and sensitization meetings to get their maximum support in terms of providing land and labour for tree planting. The results will contribute to the attainment of the Bonn challenge commitment of Uganda by reinforcing the strategies of improving involvement and coordination of all stakeholders. A multi-stakeholder innovations platform should be established to bring and keep these stakeholders together and enable them to enhance each other's capacities. A stakeholder analysis by only independent analysts may reveal more stakeholders and worth undertaking in other studies.

\section{Declarations}

\section{List of abbreviations:}

CFM: Collaborative Forest management

CSO: Civil Society Organization

FMNR: Farmer Managed Natural Regeneration

IUCN: International Union for Conservation of Nature and Natural Resources
LC: Local council

LG: Local Government

MWE: Ministry of water and environment

NEMA: National Environmental Management Authority

NFA: National Forestry Authority

NORAD: Norwegian Agency for Development

REDD+: Reducing Emissions from Deforestation and forest Degradation + the role of conservation, sustainable management of forests and enhancement of forest carbon stocks

SC: Sub County

SH: Stakeholder

SPGS: Saw log Production Grant Scheme

URDT: Uganda Rural Development and Training

WVU: World Vision Uganda

Ethics approval and consent to participate: Permission to conduct the project was provided by the Uganda National Council for Science and Technology (NS - 511). All participants provided Prior Informed Consent.

\section{Consent for publication: Not applicable}

Availability of data and materials: Not applicable

Competing interests: There are no financial and non-financial competing interests regarding this work

Funding: This work was financially supported by Norwegian Agency for Development Cooperation (NORAD) through the Norwegian Program for Capacity Development in Higher Education and Research for Development (NORHED) project (UGA-13/0019).

Authors' contributions: The corresponding author (Charles L. Tumuhe) conceptualized the research idea, collected, analyzed the data and prepared the manuscript. Juliet Kiguli provided technical guidance at all stages of this work.

Acknowledgement: I appreciate my supervisor: Professor J.R.S Tabuti for supervising this work. I thank local residents of Kiryanga SC for accepting to give me information and the Sub County administration for permitting me to collect data from their area. I am grateful to NORAD through the NORHED project (UGA-13/0019) for financially supporting this work. Finally, I thank the Uganda National Council for Science and Technology (NS 511) for permitting me to carry out this study.

\section{Author Affiliations}

Charles L. Tumuhe ${ }^{1,2^{*}}$ and Juliet Kiguli ${ }^{1}$ 
${ }^{1}$ Department of environmental management, Makerere University, P. O. BOX 7062, Kampala, Uganda

${ }^{2}$ African Rural University, P. O. BOX 24, Kagadi, Uganda

*Corresponding author: tumchaz34@gmail.com

\section{Literature cited}

Gross-camp N, Adrian M, Munyarukaza J, McGuire S, Kebede B. 2012. The payment for ecosystem services project. Fauna and flora international, Kampala, Uganda.

Hyder A, Syed S, Puvanachandra P, Bloom G, Sundaram S, Mahmood S, lqbal M. 2010. Stakeholder analysis for health research: Case studies from low- and middle-income countries. Public health 124(3):159-66.

IUCN. 2018. Assessing IUCN contribution to Uganda's forest landscape restoration processes. Kampala, Uganda.

Kakuru OV, Doreen M, Wilson M. 2014. Adoption of on-farm tree planting in Kibaale District, Western Uganda. Journal of sustainable forestry 33(1):87-98.

Langdale BI, Osmaston HA, Wilson JG. 1964. The vegetation of Uganda and its bearing on land use. Government printer, Kampala, Uganda.

Lin D, Lin Y. 2015. Stakeholders of voluntary forest carbon offset projects in China: An empirical analysis. Advances in meteorology. 2015:1-7.

Luyet V, Schlaepfer R, Parlange MB, Buttler A. 2012. A framework to implement stakeholder participation in environmental projects. Journal of environmental management 111:213-19.

Mayers J. 2005. Stakeholder power analysis. Focus. IIED. http://www.policypowertools.org/Tools/Understanding/docs/stakehold er power tool english.pdf.

Ministry of Water and Environment. 2016a. Forest landscape restoration opportunity assessment for Uganda (2016). Kampala, Uganda.

Ministry of Water and Environment. 2016b. State of Uganda's forestry 2016. Kampala, Uganda.

Namazzi G, Kiwanuka SN, Waiswa P, Bua J, Okui O, Allen KA, Hyder AA, Kiracho EE. 2013. Stakeholder analysis for a maternal and newborn health project in Eastern Uganda. BMC pregnancy and childbirth 13.

National Environmental Management Authority. 2009. Fourth national report to the convention on biological diversity. Kampala, Uganda.

National Environmental Management Authority. 2016. National state of the environment report 2016/17. Kampala, Uganda.
National Planning Authority. 2013. Uganda Vision 2040. Kampala, Uganda. http://npa.ug/ugandavision-2040/.

Nyakana F, Nyakana G. n.d. Kibaale District hydrochemical characteristics map.

Peskett L, Schreckenberg K, Brown J. 2011. Institutional approaches for carbon financing in the forest sector: Learning lessons for REDD+ from forest carbon projects in Uganda. Environmental science and policy 14(2):216-29.

Plumptre A. 2002. Extent and status of the forests in the Ugandan Albertine Rift. Kampala, Uganda.

Richards M, Panfil S. 2011. Social and biodiversity impact assessment manual for REDD+ projects: Part 2 - Social impact assessment toolbox. Climate, community \& biodiversity alliance and forest trends with rainforest alliance and fauna \& flora international, Washington DC, USA.

Salmond JA, Tadaki M, Vardoulakis S, Arbuthnott K, Coutts A, Demuzere M, Dirks KN, Heaviside C, Lim S, Macintyre H, Mclnnes RN, Wheeler BW. 2016. Health and climate related ecosystem services provided by street trees in the urban environment. Environmental Health 15(36):95-111.

Uganda Bureau of Statistics. 2016. National population and housing census 2014 - main report. Uganda Bureau of Statistics, Kampala, Uganda.

Weperen EV. 2013. A practical method for selecting stakeholders in local landscape planning for ecosystem services. Wageningen University, Wageningen, Belgium.

Wieland M. 2012. Murchison - Semliki REDD+ project free, prior and informed consent approach. Kampala, Uganda.

World Vision Uganda. 2014. 2014 Annual report. Kampala, Uganda. 